\title{
COMMENTS
}

\section{Conspiring Drug Kingpins: Twice in Jeopardy?}

\author{
Janet Bauman'
}

In 1970, Congress enacted the Controlled Substances Act ${ }^{1}$ to improve enforcement of the drug laws. ${ }^{2}$ The Act shifted the focus of drug enforcement efforts from strict penalties against small-time users to more severe punishment for drug peddlers. ${ }^{3}$ As part of the Act, Congress defined a new crime, "continuing criminal enterprise" ("CCE"), to serve as an additional vehicle to punish the leaders of extensive drug networks. ${ }^{4} \mathrm{CCE}$ is a compound crime. To

$\dagger$ A.B. 1988, Stanford University; J.D. Candidate 1994, The University of Chicago.

1 The Controlled Substances Act constitutes Title II of the Comprehensive Drug Abuse Prevention and Control Act of 1970 ("CDAPCA"), Pub L No 91-513, 84 Stat 1236, 1242 (1970), Title II codified at 21 USC $\$ 801-904$ (1988).

2 See 21 USC \& 801(6) (1988).

s Comprehensive Drug Abuse Prevention and Control Act of 1970, HR Rep No 91-1444 (Part 1), 91st Cong, 2d Sess, reprinted in 1970 USCCAN 4566, 4570. The Supreme Court has noted that the purpose of the statute is to punish the drug kingpins or "top brass" in drug rings. Garrett v United States, 471 US 773, 781 (1985). See also Susan W. Brenner, S.C.A.R.F.A.C.E.: A Speculation on Double Jeopardy and Compound Criminal Liability, 27 New Eng L Rev 915, 935-36 (1993) (statute targets "drug executives").

- 21 USC § 848 (1988 \& Supp 1991). Under this statute, a person is engaged in a continuing criminal enterprise if-

(1) he violates any provision of this subchapter or subchapter II of this chapter the punishment for which is a felony, and

(2) such violation is a part of a continuing series of violations of this subchapter or subchapter II of this chapter-

(A) which are undertaken by such person in concert with five or more other persons with respect to whom such person occupies a position of organizer, a supervisory position, or any other position of management, and

(B) from which such person obtains substantial income or resources.

21 USC $\S 848(c)$. 
prove it, the government must show that the defendant committed other felony violations, or predicate offenses, of the Controlled Substances Act.

The compound nature of $\mathrm{CCE}$ has raised many questions about a defendant's Fifth Amendment guarantee against being placed in jeopardy twice for the same offense. ${ }^{5}$ The Double Jeopardy Clause offers three constitutional safeguards. It "protects against a second prosecution for the same offense after acquittal. It protects against a second prosecution for the same offense after conviction. And it protects against multiple punishments for the same offense." The crux of the inquiry into a potential denial of any of these protections is often an examination of whether two offenses are "the same offense." In the CCE context, the question is whether CCE is "the same" as its predicate offenses.

In Blockburger $v$ United States, the Supreme Court set forth a test for determining whether cumulative punishment or consecutive prosecutions for two statutory provisions violate the Double Jeopardy Clause: two offenses are not the "same" for purposes of the Clause if "each requires proof of a fact which the other does not." If all of the elements of one offense are included in the definition of another, then the first offense is a "lesser-included offense" of the second. ${ }^{8}$ In general, once a defendant has been prosecuted or punished for one offense, he may not be prosecuted or punished for a violation of the other. ${ }^{9}$

In the last two decades, the Court has recast the Blockburger test as a method of construing Congress's intent, rather than interpreting it as a strict rule for finding a violation of the cumulative punishment aspect of double jeopardy protection. ${ }^{10}$ Under this ap-

s "[N]or shall any person be subject for the same offence to be twice put in jeopardy of life or limb." US Const, Amend V.

${ }^{8}$ North Carolina v Pearce, 395 US 711, 717 (1969). See also United States v Dixon, 113 S Ct 2849, 2855-56 (1993); Albernaz v United States, 450 US 333, 343 (1981); Brown v Ohio, 432 US 161, 165 (1977).

284 US 299, 304 (1932).

Brown, 432 US at 164, 168-69.

Id at 165, 168-69. Under certain circumstances, this rule does not apply. For example, if all of the facts necessary to prove the greater offense had not yet occurred at the time the defendant was prosecuted for the lesser offense, or if the government, exercising due diligence, could not have discovered the greater offense, then the government may prosecute the greater offense after prosecuting the lesser offense without violating the defendant's double jeopardy rights. Id at $169 \mathrm{n} 7$.

10 See Ianelli v United States, 420 US 770, 785 n 17 (1975); Whalen v United States, 445 US 684, 691 (1980); Albernaz, 450 US at 337; Missouri v Hunter, 459 US 359, 369 (1983); Garrett, 471 US at 778-79; Dixon, $113 \mathrm{~S} \mathrm{Ct}$ at 2882 (Souter concurring in the judgment in part and dissenting in part). 
proach, the Double Jeopardy Clause "does no more than prevent the sentencing court from prescribing greater punishment than the legislature intended." Congress can associate any reasonable punishment with a particular offense. ${ }^{12}$ Accordingly, the double jeopardy prohibition against multiple punishments does not prohibit cumulative sentencing for a lesser-included offense if Congress intended such a result. ${ }^{13}$ If so, the offenses are not "the same" for double jeopardy purposes. Thus, to analyze whether cumulative punishment for conspiracy and $\mathrm{CCE}$ violates the prohibition against double jeopardy, one must focus on what punishment Congress intended.

The Supreme Court has applied a cumulative punishment analysis in the CCE context twice. In Jeffers $v$ United States, Justice Blackmun, writing for a plurality, decided that Congress did not intend cumulative punishment for CCE and conspiracy. ${ }^{14} \mathrm{Al}-$ though a majority of the Court agreed that cumulative punishment was prohibited, the justices split in their reasoning. ${ }^{15}$ Later, in Garrett $v$ United States, the Court considered substantive violations of the Controlled Substances Act as predicate offenses for $\mathrm{CCE}^{16}$ and determined that cumulative punishment was constitutional in that context. ${ }^{17}$ Although the Garrett Court distinguished Jeffers instead of overruling it, ${ }^{18}$ Garrett seriously undermines the reasoning of the Jeffers plurality. Still, every lower court to con-

11 Grady $v$ Corbin, 495 US 508, 516-17 (1990), citing Hunter, 459 US at 366.

12 The only constitutional limit to the punishment that a legislature may impose upon a criminal offender is that the punishment may not be cruel and unusual. US Const, Amend VIII.

13 For example, Garrett allowed punishment for a predicate offense and CCE, but nonetheless stated that a predicate offense to CCE is a lesser-included offense, because it "does not require proof of any fact not necessary to the CCE offense." 471 US at 778. No limitation on the powers of Congress prevents it from punishing greater offenses as well as lesser ones included within them. Congress may set whatever level of punishment it chooses for the greater offense; thus, it may split the greater offense into lesser ones and punish those as well. Id at 778-79.

14432 US 137, 155 (1977). Two different conspiracy provisions of the Comprehensive Drug Abuse Prevention and Control Act, Pub L No 91-513, 84 Stat 1236, 1291 (1970), may serve as felony violations of the narcotics laws. See 21 USC $\$ 846$ (1988) (conspiracy to manufacture or distribute); 21 USC $\$ 963$ (1988) (conspiracy to import or export). Section 846 appears in the Controlled Substances Act, Title II of CDAPCA; \& 963 appears in Title III.

${ }^{15}$ See 432 US at $160 \mathrm{n} 7$ (Stevens dissenting in part and concurring in the judgment in part).

18 A "substantive predicate offense" is simply a non-conspiracy offense. See 471 US at 794. See also United States v Maza, 983 F2d 1004, 1009 (11th Cir 1993).

17471 US at 790.

18 Id at 794-95. 
sider the issue of cumulative punishment for CCE and conspiracy, either as a predicate offense or as a separate prosecution, has followed Jeffers and disallowed cumulative punishment. ${ }^{19}$

This Comment argues that cumulative punishment for CCE and conspiracy is in fact constitutionally permissible. The decisions not to allow cumulative punishment are based on inconsistent and outdated reasoning that demands reconsideration. Section I explores the reasoning underlying the current law that prohibits cumulative punishment, focusing largely on Jeffers. Section II argues that the Garrett Court's analysis of double jeopardy under the Controlled Substances Act should supplant the reasoning of Jeffers so as to allow cumulative punishment. Section III argues that post-Jeffers developments in the Federal Sentencing Guidelines and the Racketeer Influenced and Corrupt Organizations Act ("RICO") indicate that cumulative punishment should be permitted in order to effectuate congressional intent.

19 See, for example, United States v Rivera-Martinez, 931 F2d 148, 152-53 (1st Cir 1991); United States v West, 877 F2d 281, 292 (4th Cir 1989); United States v Schuster, 769 F2d 337, 345 (6th Cir 1985); United States v Possick, 849 F2d 332, 341 (8th Cir 1988); United States $v$ Hernandez-Escarsega, 886 F2d 1560, 1582 (9th Cir 1989); United States $v$ Rivera, 900 F2d 1462, 1478 (10th Cir 1990); United States v Reed, 980 F2d 1568, 1581 (11th Cir 1993).

Although these courts agree that cumulative punishment for conspiracy and continuing criminal enterprise is not allowed, they do differ with respect to their sentencing procedures. See generally Note, Continuing Criminal Enterprise, Conspiracy, and the Multiple Punishment Doctrine, 91 Mich L Rev 2220 (1993).

The Court of Appeals for the Seventh Circuit allows concurrent, but not consecutive, sentences for both convictions, arguing that conspiracy and continuing criminal enterprise are not alternative crimes, that the conviction for conspiracy may later have informational value, and that Jeffers allows this result. United States $v$ Bafia, 949 F2d 1465, 1474-75 (7th Cir 1991), cert denied as Kerridan v United States, 112 S Ct 1989 (1992); United States v Canino, 949 F2d 928, 949 (7th Cir 1991), cert denied, 112 S Ct 1701 (1992); United States $v$ Bond, 847 F2d 1233, 1238-39 (7th Cir 1988).

Other courts combine the convictions and impose a general sentence without vacating the conspiracy conviction, claiming that such a sentence is consistent with Jeffers, that Congress intended for the two convictions to stand, and that the procedure does not offend any of the purposes of the Double Jeopardy Clause. United States $v$ Aiello, 771 F2d 621, 633-34 (2d Cir 1985); United States v Fernandez, 916 F2d 125, 128 (3d Cir 1990); United States $v$ Grayson, 795 F2d 278, 287 (3d Cir 1986); United States v Gomberg, 715 F2d 843, 851 (3d Cir 1983); United States v Gomez, 593 F2d 210, 217-19 (3d Cir 1979).

The Court of Appeals for the Ninth Circuit recently allowed an alternative sentencing approach in which the conspiracy sentence would kick in if the conviction for continuing criminal enterprise were later reversed. United States $v$ Medina, 940 F2d 1247, 1253 (9th Cir 1991), cert denied, 112 S Ct 900 (1992). This court was primarily concerned with losing a conviction on appeal and decided that Congress intended for at least one sentence to be carried out. 


\section{Analysis of Current Law}

When Congress created the continuing criminal enterprise offense, it did not expressly state in the statute or in the legislative history whether a conviction for CCE would result in punishment in addition to, or in lieu of, punishment for predicate offenses. Congress also did not state whether a conspiracy charge would merge into a CCE charge. Thus, courts have resorted to various means of statutory interpretation in order to divine Congress's intent with respect to cumulative punishment. Courts have been almost unanimous in finding that Congress did not intend cumulative punishment for conspiracy and $\mathrm{CCE} .{ }^{20}$ In general, these courts have adopted the reasoning of the plurality opinion in Jeffers $v$ United States.

\section{A. The Facts of Jeffers}

Garland Jeffers and five others created an enterprise known as "the Family" to control drug traffic in Gary, Indiana. ${ }^{21}$ From 1972 to 1974, Jeffers exercised ultimate authority in the organization with respect to both finances and discipline. ${ }^{22}$ The Family distributed heroin, earning revenues of about $\$ 5000$ a day, with Jeffers's personal share exceeding $\$ 1$ million over the two years in which the Family operated..$^{23}$

A federal grand jury returned indictments against Jeffers, charging him and nine others with conspiracy to distribute heroin and cocaine, and adding a CCE charge against Jeffers alone. The Government moved to try all of the charges together, but Jeffers and his codefendants objected. The codefendants claimed that the evidence presented to prove the CCE charge would confuse the jury. Jeffers argued that many of the overt acts the Government intended to offer in order to prove the conspiracy did not involve him and would therefore be inadmissible to prove the CCE. The district court denied the motion to try the cases together. ${ }^{24}$

${ }^{20}$ The Third Circuit has found that Congress intended for both convictions to stand. United States v Fernandez, 916 F2d 125, 128 (3d Cir 1990). This may constitute multiple punishment under Ball $v$ United States, 470 US 856 (1985).

21 Jeffers, 432 US at 139.

22 Jeffers "exercised ultimate authority over the substantial revenues derived from the Family's drug sales, extortionate practices, and robberies. He disbursed funds to pay salaries of Family members, commissions of street workers, and incidental expenditures." Id. Moreover, "he maintained a strict and ruthless discipline within the group, beating and shooting members on occasion." Id at 140.

23 Id.

24 Id at $140-43$. 
The conspiracy counts proceeded to trial first. Jeffers was found guilty of conspiracy to distribute heroin and cocaine and sentenced to 15 years in prison and a fine of $\$ 25,000 . .^{25}$. The CCE charge then went to trial, despite Jeffers's attempts to have it dismissed on double jeopardy grounds. Jeffers was again found guilty and given the maximum sentence-life imprisonment and a $\$ 100,000$ fine. ${ }^{26}$ Before the Supreme Court, Jeffers argued that the second prosecution violated his double jeopardy rights. A plurality of the Court found that by objecting to the Government's motion to try the conspiracy and CCE charges together, Jeffers had waived his rights against double jeopardy. ${ }^{27}$

Then, although neither party had raised the issue, the Court considered whether the cumulative sentences violated the double jeopardy protection against multiple punishment. A plurality of the Court concluded that the two prison sentences for conspiracy and CCE did not violate the Double Jeopardy Clause because they did not exceed the maximum allowable under $\S 848$, the CCE provision. However, as the cumulative fines were greater than the maximum allowable for CCE, the Court ruled that the fines had to be reduced so that they did not exceed the statutory maximum of $\$ 100,000 .^{28}$

\section{B. The Plurality Opinion-Cumulative Punishment Disallowed}

The Jeffers plurality advanced three primary arguments for prohibiting cumulative punishment for conspiracy and CCE: (1) the structure of the CCE statute leaves little room for cumulative punishment in the form of consecutive sentences; (2) the legislative history on cumulative punishment is inconclusive and therefore does not support the conclusion that Congress intended the punishment to be cumulative; and (3) the dangers underlying each crime present little need for cumulative punishment. ${ }^{29}$ Furthermore, the plurality found that Congress probably intended conspiracy to be a lesser-included offense of CCE (although resolution of this issue was unnecessary to the decision).$^{30}$

\footnotetext{
${ }^{25}$ Id at 143 (violation of 21 USC $\$ 841(a)(1)$ ).

${ }^{26}$ Id at $144-45$.

27 Id at 153-54.

${ }^{28}$ Id at 157-58.

${ }^{29}$ Id at 156-57.

30 Id at 149-50.
} 
1. Structure of the statute.

In his plurality opinion, Justice Blackmun claimed that $\S 848$ "reflects a comprehensive penalty structure that leaves little opportunity for pyramiding of penalties from other sections of the Comprehensive Drug Abuse Prevention and Control Act of 1970."31 The statute authorizes a maximum sentence of life imprisonment, together with a fine and forfeiture of all profits, for a firsttime offender. ${ }^{32}$ This maximum penalty gives sentencing judges all the upward flexibility they need to punish drug kingpins severely. Additional punishment for conspiracy is unnecessary because Congress allowed the maximum punishment possible for defendants who run continuing criminal enterprises. ${ }^{33}$ Furthermore, noted the plurality, $\S 848$ forbids probation or parole and was the only drug control statute that provided for mandatory minimum sentences. ${ }^{34}$ Finally, $\S 848$ specified a maximum fine of $\$ 100,000$, or $\$ 200,000$ for second offenders. ${ }^{35}$ Since by definition a violation of $\S 848$ includes other violations of the Controlled Substances Act, Justice Blackmun concluded that "there would have been no point in specifying maximum fines for the $\S 848$ violation if cumulative punishment was to be permitted." 36

\section{Legislative history.}

Justice Blackmun then considered the legislative history of $\S 848$ and found it "inconclusive on the question of cumulative punishment." ${ }^{\prime 37}$ While Congress intended to punish professional drug dealers severely, the penalty scheme for CCE "was to be separate from the rest of the penalties." ${ }^{38}$ Because the legislative history did not specifically indicate whether defendants could be cumulatively punished for conspiracy and $\mathrm{CCE}$, the plurality found "no reason to deviate from the result suggested by the structure of the statute itself." 39

31 Id at 156.

3221 USC § 848(a) (1988).

ss Jeffers, 432 US at 157.

34 Id at 156.

3s The maximum fine is now $\$ 2,000,000$. 21 USC $\S 848(\mathrm{a})$.

${ }^{36} 432$ US at 156.

${ }^{37}$ Id. See also United States v Chagra, 653 F2d 26, 32 (1st Cir 1981).

38 Jeffers, 432 US at $156 \mathrm{n} 26$.

so Id. The court in United States v Sperling, 560 F2d 1050 (2d Cir 1977), inquired further into the legislative history of the CCE provision. The court there found that CCE was originally intended as an alternative sentencing provision for defendants "who engaged in extensive violations of the narcotics laws. . . ." Id at 1057. However, in light of the dubi- 
3. Dangers to be avoided.

The plurality in Jeffers then determined that the dangers sought to be avoided by the two statutes did not require cumulative punishment. ${ }^{40}$ The reason to punish conspiracy in addition to its substantive object is that collective criminal action poses a greater threat to society than individual action: "Concerted action both increases the likelihood that the criminal object will be successfully attained and decreases the probability that the individuals involved will depart from their path of criminality."41 Moreover, partners in a conspiracy tend to complete more complex crimes and are more likely to commit offenses in addition to those the conspirators originally intended to commit. ${ }^{42}$ Because $\S 848$ already prohibits this kind of conduct, the plurality concluded that Congress had no reason to authorize cumulative punishment. ${ }^{43}$

\section{Lesser-included offense.}

Many courts have applied a Blockburger analysis-either as an indicator of congressional intent or as a strict rule-to the two offenses of conspiracy and CCE. ${ }^{44}$ The plurality in Jeffers considered a Blockburger analysis but declined to decide squarely whether conspiracy was a lesser-included offense of $\mathrm{CCE}^{45}$ In order for conspiracy to constitute a lesser-included offense of CCE, Blockburger requires that all of the elements of conspiracy be elements in the definition of CCE. ${ }^{46}$ Accordingly, the plurality consid-

ous constitutionality of some aspects of the original CCE proposal (which would have allowed the use of hearsay without cross-examination, allowed the sentencing judge to withhold parts of the presentence report from the defendant, and would have placed the burden on the defendant to show that his income came from sources other than drugs), Congress amended the proposal to make CCE a distinct offense. According to the Sperling court, this development indicates that "what originated as a harsh sentencing alternative remained as such in the enacted statute, but with all our constitutional guaranties preserved." Id.

10432 US at 157. See also United States $v$ Gomberg, 715 F2d 843, 849-50 (3d Cir 1983). But see United States $v$ Fernandez, 916 F2d 125, 127-29 (3d Cir 1990) (because the conspiracy statute and CCE had different purposes, both convictions could stand, although the total sentence may not exceed the maximum allowed under $\mathrm{CCE}$ ).

11 Jeffers, 432 US at 157, quoting Callanan v United States, 364 US 587, 593 (1961).

42 Id at 157, quoting Callanan, 364 US at 593-94.

43432 US at 157.

4 See, for example, United States v Aiello, 771 F2d 621, 634 (2d Cir 1985); Sperling, 560 F2d at 1054-55.

'45 432 US at 149-50 ("[W]e assume, arguendo, that . . \& 846 is a lesser included offense of $\S 848$."). The plurality found it unnecessary to decide the lesser-included offense issue because the defendant had waived his double jeopardy rights against consecutive prosecution by demanding separate trials for the conspiracy and CCE charges. Id at 153-54.

${ }^{18}$ See Blockburger, 284 US at 304. 
ered whether the language of the CCE statute-which requires the defendant to undertake a continuing series of violations "in concert with" at least five others-was the same as the "agreement" required for a conspiracy conviction. In rejecting the Government's argument that "one professional criminal might have 'conned' five innocent dupes into working for him," thus technically avoiding any "agreement" while still acting "in concert with" others, the plurality noted that the general meaning of the term and the legislative history indicated that the words "in concert with" encompassed the traditional meaning of "agreement." concluded that conspiracy was probably a lesser-included offense of CCE. ${ }^{48}$ Most lower courts have adopted these dicta in holding that conspiracy is a lesser-included offense and thus cannot be punished along with $\mathrm{CCE} .^{49}$

\section{The Other Jeffers Opinions}

Justice Stevens, writing for himself and three other justices, believed that conspiracy was a lesser-included offense of CCE: "There is nothing novel about the rule that a defendant may not be tried for a greater offense after conviction of a lesser included offense." Bocause Justice Stevens would have barred the subsequent conviction, he also would have barred multiple punishment. While he therefore agreed with the plurality that the cumulative fines should be vacated, Justice Stevens provided no reasoning to support the conclusion that neither multiple prosecutions nor multiple punishments were allowed. Instead, he concentrated on the other principal holding of the plurality-that the defendant had waived his double jeopardy rights by failing to demand one proceeding for both the conspiracy and CCE charges. ${ }^{.1}$

Justice White, on the other hand, believed that the Constitution permitted both the second conviction and the cumulative punishment. ${ }^{52}$ In a one-paragraph opinion, Justice White argued that an earlier decision of the Court, Iannelli $v$ United States, ${ }^{\mathrm{53}}$ controlled. In Iannelli, the Court held that a defendant could be convicted under both the federal conspiracy statute and a statute

17. Jeffers, 432 US at 148-49 n 14.

4s Id at 150 .

40 See, for example, the cases cited in note 19. part).

so Jeffers, 432 US at 158 (Stevens dissenting in part and concurring in the judgment in

si Id at $158-60$.

82 Id at 158 (White concurring in the judgment in part and dissenting in part).

ss 420 US 770 (1975). 
prohibiting gambling businesses involving five or more persons, even when the conspiracy was to violate the gambling statute. ${ }^{54}$ The thrust of Iannelli was that Wharton's Rule, which requires a conspiracy charge to be merged into its substantive object if completing the object requires more than one actor, ${ }^{\mathrm{bS}}$ did not require the merger of the conspiracy and gambling charges, because of legislative intent to the contrary ${ }^{56}$ Furthermore, the two statutes survived the Blockburger analysis because the gambling statute did not have an "agreement" as an element."

The Government argued in Jeffers, and Justice White agreed, that like the gambling statute in Iannelli, CCE did not require an "agreement" and thus was not the "same offense" as conspiracy. ${ }^{58}$ Justice White also concluded that Jeffers's cumulative sentences did not violate the Double Jeopardy Clause because the prosecution did not use the conspiracy established at the earlier trial to prove the continuing criminal enterprise charged in the subsequent trial. Thus, Justice White did not agree that the fines had to be reduced. ${ }^{59}$

\section{Analysis of Cumulative Punishment Under Current Law}

Developments in the law since Jeffers suggest at the very least that lower courts should reconsider their adherence to the plurality's holding, and quite possibly that the Jeffers plurality was simply wrong to begin with-that it misread the Congressional intent

See id at $772 \mathrm{n} 1$, citing 18 USC $\$ 371$ (1970) (conspiracy); id at $772 \mathrm{n} 2$, citing 18 USC $\S 1955$ (a)-(b) (1970 \& Supp III) (gambling business).

${ }_{5 s}$ The commentator Francis Wharton, whose name this rule bears, originally formulated the rule: "When to the idea of an offense plurality of agents is logically necessary, conspiracy, which assumes the voluntary accession of a person to a crime of such a character that it is aggravated by a plurality of agents, cannot be maintained." Francis Wharton, 2 Criminal Law \$ 1604 (Lawyers Co-op, 12th ed 1932).

${ }^{86}$ Iannelli, 420 US at 786-91. The Court found much evidence of legislative intent to the contrary. First, the basic purpose of the Organized Crime Control Act of 1970 was to eradicate organized crime by providing enhanced sanctions and new remedies to deal with those involved in organized crime. Congress enacted $\S 1955$ as a weapon to combat the substantive evil of large-scale gambling operations. Second, the Court found that in drafting the Act, Congress manifested an awareness of the distinct nature of conspiracy and substantive offenses. In one provision, Congress identified "special offenders" as those who committed specific felonies and as those who committed conspiracies. Moreover, Congress specifically used the law of conspiracy to enhance penalties and remedies against those involved in organized crime. Finally, the definition of gambling activities in $\S 1955$ did not refer to either "conspiracy" or "agreement." The Court concluded that if Congress had intended to preclude prosecution for conspiracy and $\S 1955$, it would have said so explicitly. Id.

s7 Id at $785 \mathrm{n} 17$.

ss Jeffers, 432 US at $147,158$.

69 Id at 158. 
underlying the continuing criminal enterprise statute. First, the Supreme Court in Garrett $v$ United States reevaluated the language, structure, and legislative intent behind $\S 848$, reaching conclusions contrary to those of the Jeffers plurality. ${ }^{60}$ Applying the reasoning of Garrett to the facts of Jeffers indicates that Congress probably intended cumulative punishment for drug conspiracy and CCE. Furthermore, the Court has rejected the use of the Blockburger analysis for compound offenses such as CCE.

\section{A. Garrett $v$ United States}

In 1985, the Supreme Court considered an issue closely related to cumulative punishment for conspiracy and CCE. In Garrett, the Court examined the double jeopardy implications of a CCE prosecution when the "facts underlying a prior conviction are offered to prove one of three predicate offenses" necessary to establish a CCE violation. ${ }^{61}$ The Court concluded that double jeopardy did not prohibit cumulative punishment for substantive predicate offenses and CCE.

From 1976 to 1981, Jonathan Garrett directed an extensive organization that imported and distributed marijuana. In March of 1981, he was charged with importing marijuana and named as an unindicted co-conspirator to a conspiracy charge. He eventually pled guilty to the importing charge and was sentenced to five years in prison and a $\$ 15,000$ fine. ${ }^{62}$ Two months later, Garrett was indicted for CCE and other narcotics offenses in a different district. To prove the CCE, the Government introduced evidence of the importation that had led to the earlier guilty plea. Garrett was found guilty and sentenced to 40 years' imprisonment, to run consecutively with his earlier sentence for importing marijuana. The Supreme Court granted certiorari to answer the question of whether the second prosecution or the cumulative punishment violated the principles of double jeopardy. ${ }^{63}$

Contrary to the Jeffers plurality, the Court in Garrett concluded that the language, structure, and legislative history of the Controlled Substances Act showed that Congress intended CCE to be a separate offense punishable in addition to, and not as an alternate for, predicate offenses. Thus, the Court held that cumulative punishment in this context did not violate the Double Jeop-

\footnotetext{
471 US 773 (1985).

61 Id at 775 .

62 Id.

${ }^{63}$ Id at 776-77.
} 
ardy Clause. ${ }^{64}$ The Garrett Court distinguished Jeffers but gave little reason for doing so, claiming only that the "dangers posed by a conspiracy and a CCE were similar," whereas the dangers posed by the CCE and the underlying substantive offenses were not. ${ }^{65}$ Because Garrett strongly suggests that predicate offenses of all kinds should be punished cumulatively with $\mathrm{CCE}$, this distinction may simply reflect the Court's refusal to reconsider the factual situation of Jeffers when it was unnecessary to do so.

The Garrett Court first explained that the language and the structure of the statute clearly showed that Congress intended CCE to be a separate offense. The statute was not drafted as a recidivist statute. Rather, the Court found that the language of the statute was aimed specifically at a particular problem-the threat posed by the top leaders in drug operations. ${ }^{66}$

The Court buttressed its language argument with an inquiry into the statute's legislative history. This history showed that Congress intended CCE to be a separate offense that could be punished separately. ${ }^{67}$ The Supreme Court recognized that the statute was originally introduced as a recidivist provision, then amended to make CCE a distinct offense. But rather than interpret the amendment as evidence that Congress intended the statute to be an alternative sentencing procedure, the Court saw the amendment as an indication that Congress meant for CCE to be separately triable and punishable. ${ }^{68}$ Furthermore, the debate in the House of Representatives on the amendment focused on the distinction between providing for longer sentences and creating separate offenses, indicating that Congress understood the difference between the two and intended to create the latter. ${ }^{69}$

64 Id at 779.

${ }^{65}$ Id at 794 ("The focus of the analysis in Jeffers was the permissibility of cumulative punishments for conspiracy under $\S 846$ and for CCE under $\S 848$, and the plurality reasonably concluded that the dangers posed by a conspiracy and a CCE were similar and thus there would be little purpose in cumulating the penalties.").

${ }^{68}$ Id at 781-82.

${ }^{87}$ Id at 782.

es Id at 781-83.

${ }^{69}$ Id at 783-84. See also HR Rep No 91-1444, 1970 USCCAN at 4651 (cited in note 3) (Additional Views) ("Instead of providing a postconviction-presentencing procedure, "the amendment] made engagement in a continuing criminal enterprise a new and distinct offense with all its elements triable in court."); 116 Cong Rec 33302 (1970) (remarks of Representative Eckhardt) ("[T]he committee decided that the Dingell amendment should be chosen over the original language ... [because] the Dingell amendment created a new offense which would have to be triable in all its parts whereas . . . the original bill . . . provided that some report upon which sentence would be based would be available to the judge ...."). 
After determining that Congress intended to create a separate offense, the Court considered whether Congress intended CCE to serve as an alternative punishment for the predicate offenses. Although the legislative history was silent as to whether Congress intended cumulative punishment for $\mathrm{CCE}$ and predicate offenses, the Court was not surprised: "[S] uch a statement would merely have stated the obvious."70 Congress was giving prosecutors a new weapon to use in addition to the already existing offenses. It therefore would not make sense for CCE to serve merely as an alternative sentencing provision, instead of as additional punishment for big-time drug offenders. Congress thought of CCE as providing further punishment for the most serious violators-those who could not be punished enough with sentences for already existing crimes. ${ }^{71}$

Having determined that Congress intended to make CCE a separate offense, the Garrett Court then adopted a presumption that when Congress creates two distinct offenses, it intends to permit cumulative sentences. ${ }^{72}$ Since the Double Jeopardy Clause does no more than prevent a sentencing court from prescribing greater punishment than Congress intended, Congress must have been aware that unless it stated a contrary position, it was authorizing cumulative punishment. ${ }^{73}$ Because this presumption is antithetical to the Blockburger test, it is unclear exactly how far the Court thought it could be carried. Taken to the extreme, this presumption may mean that a defendant could be punished for assault and murder arising out of the same killing, or even for assault and assault with intent to kill, if the legislature had codified these as two distinct provisions. ${ }^{74} \mathrm{~A}$ literal reading also calls into question Whalen $v$ United States, where the Court held that a defendant convicted of rape and felony murder based on the rape could

${ }^{70} 471$ US at 784. But see Albernaz v United States, 450 US 333, 341-42 (1981), where the Court found that Congress legislated with Blockburger in mind. Thus, if two statutory offenses survived the test, they were automatically separate offenses. By the logic of $\mathrm{Al}$ bernaz, the absence of any clear indication that Congress intended cumulative punishment implies that Blockburger should govern.

71471 US at $784-85$.

72 Id at 793.

73 Id at 793-94, quoting Albernaz, 450 US at 341-42.

${ }^{74}$ For example, in the Model Penal Code, assault is a lesser-included offense of murder, but each appears in a different section. A person is guilty of assault if he "attempts to cause or purposely, knowingly or recklessly causes bodily injury to another." MPC \& 211.1 (ALI 1985). A person is guilty of murder if he purposely or knowingly causes the death of another human being. MPC $\S \S 210.1,210.2$. 
not be punished for both. ${ }^{75}$ Perhaps the best reading of the Garrett presumption is that it only applies to provisions like $\mathrm{CCE}-$ for which the legislature examined alternatives to making the offenses separate and in the end created distinct offenses.

Finally, the Court found it problematic that if cumulative punishment were not allowed, the fine allowed for CCE would become a ceiling. ${ }^{76}$ Because Congress established the large fines in order to deprive drug dealers of their enormous profits, the Court doubted "that Congress intended to force an election of a lower maximum fine [by prosecuting for CCE rather than for the predicate offenses] in order to attempt to obtain the life imprisonment penalty available under the CCE provision."'77

\section{B. Analysis of Conspiracy and CCE Under Garrett}

Following the reasoning of Garrett, the plain language and legislative history of both the conspiracy and CCE statutes-the statutes at issue in Jeffers-indicate that Congress intended cumulative punishment for violations of the two provisions. First, CCE and conspiracy are two distinct offenses, which, under the Garrett presumption, indicates that they should be punished separately. Second, the language of the two relevant conspiracy provisions, $\S 846$ and $\S 963,{ }^{78}$ suggests no reason why conspiracy as a predicate offense should be treated differently from a substantive offense. Finally, the Garrett Court's interpretation of the legislative history of the Controlled Substances Act suggests that Congress intended cumulative punishment for conspiracy as well as substantive predicate offenses.

\section{Two separate offenses.}

As the Supreme Court found in Garrett, the fact that Congress intended to create a distinct offense is at least an indication that the offense is intended to be punished separately from other offenses. ${ }^{79}$ The Garrett analysis, which resulted in the conclusion that Congress created distinct offenses, applies just as well to con-

75 445 US 684, 693-94 (1980). Undermining Whalen may be the result that Justice Rehnquist, who disagreed with that holding, intended. See id at 699 (Rehnquist dissenting). See also text accompanying notes 124-27.

${ }^{76}$ Garrett, 471 US at 794.

77 Id.

${ }^{78} 21$ USC $\$ 846$ (1988) (conspiracy to manufacture or distribute); 21 USC $\S 963$ (1988) (conspiracy to import or export).

${ }^{79} 471$ US at 784. See also Albernaz, 450 US at 336. 
spiracy as a predicate offense as it does to the substantive predicate offense at issue in Garrett. The language of the CCE statute "affirmatively states an offense for which punishment will be imposed." 80 The statute imposes its own penalty rather than modifying the penalty imposed for violations of the conspiracy provisions. Furthermore, the Controlled Substances Act has its own recidivist provision, indicating that $\mathrm{CCE}$ is a separate offense and not a recidivist offense. ${ }^{81}$ The Court goes on to note that the CCE statute is clearly aimed at the specific problem posed by the drug kingpin. ${ }^{82}$ Thus, Congress's creation of CCE as a separate and distinct statute is evidence that it intended to punish conspiracy and CCE cumulatively.

\section{Language and structure of the statutes.}

The language of $\S 846$ and $\S 963$ also leads to the conclusion that defendants should be cumulatively punished for conspiracy and $\mathrm{CCE}$. Both sections state that persons who conspire to violate specified drug laws are subject to the same punishment as if they had completed the crime. ${ }^{83}$ Since, under Garrett, a criminal who commits a substantive predicate offense can be punished for both the substantive offense and $\mathrm{CCE}$, one who conspires to commit the same offense should be subject to the same punishment. An earlier version of $\S 846$ - the one under which the defendant in Jeffers was sentenced-had specified punishment no greater than the maximum allowed for the object of the conspiracy. ${ }^{84}$ Congress amended the statute in 1988, after the Supreme Court decided Garrett, to permit the same punishment for a conspiracy as for attaining the object of the conspiracy. ${ }^{85}$ Because Congress can be assumed to know the law, ${ }^{86}$ it follows that Congress legislated with Garrett in mind and intended for the amendment to result in cumulative punishment for conspiracy and $\mathrm{CCE}$.

Bo 471 US at 779 .

82 Id at 881, citing 21 USC \& 848(a)(1).

8241 US at 881.

ss Section 846 provides that "[a]ny person who attempts or conspires to commit any offense defined in this subchapter shall be subject to the same penalties as those prescribed for the offense, the commission of which was the object of the attempt or conspiracy." 21 USC § 846. Section 963 contains the same language but refers to a different subchapter.

s4 21 USC $\S 846$ (1976). See Jeffers, 432 US at 140.

8s - See Anti-Drug Abuse Act of 1988, Pub L No 100-690, § 6470(a), 102 Stat 4377 (1988). There is essentially no legislative history for this amendment; none of the "Related Reports" listed at 1988 USCCAN 5937 (collecting legislative history of the Act) contain any mention of $\S 6470$, the relevant amendment.

sc See Garrett, 471 US at 793-94, quoting Albernaz, 450 US at 341-42. 
A comparison of the CCE statute with statutes that may serve as predicate offenses also shows that Congress may have intended cumulative punishment. Congress did not specify a maximum number of predicate offenses required for a CCE conviction. ${ }^{87}$ Thus, the sum of the fines authorized for the predicate offenses could easily exceed the maximum fine allowable under $\S 848 .^{88}$ For example, $\S 841$, which prohibits manufacturing, distributing, or dispensing controlled substances, imposes fines from $\$ 100,000$ to $\$ 8$ million. ${ }^{89}$ Even one violation of this section, for example, a second offense involving a substantial amount of drugs, ${ }^{90}$ can be punished with a fine much heavier than the maximum $\$ 2$ million CCE fine. Convictions for conspiracy under $\S 846$ allow the same punishment as the completed crime under $\S 841 .{ }^{91}$ Thus, one conviction of conspiracy to violate $\S 841$ would allow a fine higher than that allowed by CCE. Since Congress thought CCE would be the most serious of the narcotics offenses, ${ }^{92}$ it seems illogical for one convicted of a conspiracy to receive a more severe sentence. Instead, Congress must have intended for the punishments to be cumulative so that the drug kingpin remains the most severely punished of all drug offenders.

The structure of the CCE statute also refutes the argument that CCE should be considered a "super-conspiracy," of which conspiracy is a lesser-included offense. Typically, a greater offense is the more heinous crime and carries a higher penalty than its included offenses. For example, under the Model Penal Code, murder is a felony of the first degree, ${ }^{93}$ while manslaughter is a felony of the second degree. ${ }^{94} \mathrm{~A}$ felony of the first degree carries a maximum punishment of life imprisonment (or the death sentence for murder) ${ }^{95} \mathrm{~A}$ felony of the second degree is punished by a maximum of ten years. ${ }^{96}$ Thus, a defendant punished with the maximum sentence for murder would receive a higher sentence than a defendant sentenced to the maximum for manslaughter. On the

${ }^{87}$ See 21 USC § 848(c).

${ }^{88}$ Of course, because $\S 848$ allows imprisonment for life, the only part of the sentence at issue is the allowable fine. The Garrett Court was also concerned that the fine in CCE would become a ceiling, a result not intended by Congress. 471 US at 794.

${ }^{89} 21$ USC \& 841(a)-(b) (1988).

${ }^{80} 21$ USC \& 841(b)(1)(A).

91 21 USC § 846 (1988).

${ }^{92}$ See HR Rep No 91-1444 (Part 1), 1970 USCCAN at 4570 (cited in note 3).

${ }_{93}$ MPC § 210.2(2).

${ }^{84}$ MPC § 210.3(2).

${ }^{85}$ MPC $\S$ 6.06(1), 210.2(2).

${ }^{\circ 8} \mathrm{MPC} \& 6.06(2)$. 
other hand, as just seen, the maximum penalty for conspiracy may be far greater than that for CCE. If CCE were a "super-conspiracy" provision, it should carry stiffer penalties than basic conspiracy statutes.

The structure of CCE also clarifies the applicability of the Garrett presumption that two distinct offenses are separately punishable. If the elements and the penalty structure of a pair or set of statutes suggest a lesser-included relationship, the Garrett presumption should not apply. The structure would override any evidence that the legislature attempted to create two distinct offenses. Thus, the structure of homicide statutes such as the Model Penal Code, in which murder is manslaughter without the mitigating circumstance of "extreme mental or emotional disturbance," and in which murder is a first-degree felony while manslaughter is a second-degree felony, suggests that cumulative punishment for manslaughter and murder is not allowed. Indeed, the punishment for murder necessarily includes punishment for manslaughter. By contrast, although CCE arguably contains all the elements of conspiracy, ${ }^{97}$ punishment for CCE does not necessarily include punishment for conspiracy, because the penalty for conspiracy may be greater than that for CCE on the same set of facts. Thus, the structure of the statute does not rebut the Garrett presumption that Congress intends cumulative punishment when it creates two distinct offenses.

\section{Legislative history.}

The legislative history of $\S 848$ shows that Congress intended to create a separate offense, separately punishable from other offenses under the Controlled Substances Act. Garrett's analysis of the legislative history reveals that Congress intended for CCE to be an offense distinct from that of conspiracy. ${ }^{88}$ For example, the Garrett Court found significant the amendment of the original bill from an enhanced-sentence provision for "special offenders" to a distinct offense. ${ }^{99}$

Furthermore, the legislative history shows that Congress sought to avoid different dangers through each offense. Given the

${ }^{97}$ See Section II.B.5 for the contrary argument.

28 See text accompanying notes 67-69.

9 471 US at 783, citing Debate on Comprehensive Drug Abuse Prevention and Control Act of 1970, HR 1216, 91st Cong, 2d Sess, in 116 Cong Rec 33302 (Sep 23, 1970) (remarks of Representative Eckhardt). 
lack of evidence on the intent underlying $\S 846,{ }^{100}$ one can assume that the conspiracy statute focused on the traditional dangers of collective criminal groupings. Concerted action increases the likelihood that a group will succeed in its goal and makes it less likely that individual conspirators will renounce their criminal plans. Concerted action also increases the probability that the group will commit crimes outside the original criminal objects of the conspiracy. ${ }^{101}$

On the other hand, Congress enacted $\$ 848$ with the particular goal of punishing criminals who run extensive and successful drug operations. In fact, Congress seemed primarily concerned with individuals, rather than groups. The original penalty structure reflects this concern. CCE punished the leaders of the crime syndicates-those who held supervisory roles and who individually obtained substantial income from the enterprise. ${ }^{102}$ If Congress had been concerned with the dangers of concerted action, it would have had no reason to create a new offense. Simply increasing the punishment for the conspiracy offense would have served that purpose. ${ }^{103}$ Instead, Congress created a new offense to punish the leaders of profitable drug enterprises. The focus on individual culpability in the CCE statute makes it easy to see how Congress would intend to punish defendants both for agreeing to commit an illegal act and for succeeding in committing such illegal acts on a "grand scale."104

Finally, Garrett found that the legislative history gave no indication that CCE was to be a substitute for the predicate offenses underlying a CCE charge. ${ }^{105}$ With CCE, Congress intended to create a new offense, separately punishable from other drug crimes. Nothing in the legislative history indicates that conspiracy should be different from substantive offenses, or that CCE is a substitute for conspiracy. Since under Garrett any other predicate act may be punished cumulatively with CCE, conspiracy should be treated the same way.

100 The conspiracy provision is noted without discussion of purposes in HR Rep No 911444,1970 USCCAN at 4617 (cited in note 3).

${ }^{101}$ See, for example, Wayne R. LaFave and Austin W. Scott, Jr., Criminal Law § 6.5(h) at 567-68 (West, $2 \mathrm{~d}$ ed 1984).

10221 USC 848(b).

${ }^{103}$ In fact, Congress did increase the punishment for conspiracy in 1988, when it provided that conspirators could be punished as severely as if they had completed the object of the conspiracy. 21 USC \& 846.

104 United States v Bond, 847 F2d 1233, 1238 (7th Cir 1988).

106471 US at 784. 
4. Dangers protected against.

Garrett's summary distinction of Jeffers-that the dangers against which conspiracy and CCE protect are different-makes this issue an important aspect of the double jeopardy analysis. While the Garrett Court conceded that it could be "reasonable" to consider the dangers similar, ${ }^{108}$ only four justices in Jeffers actually agreed on the similarity. ${ }^{107}$ In fact, the Jeffers reasoning was that conspiratorial behavior was already prohibited by $\mathrm{CCE},{ }^{108}$ reasoning which applies to any predicate offense. All drug felonies are prohibited by CCE when the other elements of CCE are also present.

Lower courts have rejected the Jeffers conclusion that the two provisions protect against similar dangers. In so doing, one lower court refused to adopt the holding in Ball $v$ United States. ${ }^{109}$ In Ball, the Court concluded that if Congress did not intend cumulative punishment, then one of the convictions must be vacated because the conviction itself was excess punishment. ${ }^{110}$ But, the court of appeals in United States $v$ Fernandez claimed that Congress intended convictions for both conspiracy and CCE to stand, even if it did not intend to allow cumulative prison sentences. ${ }^{111}$ The primary argument in Fernandez was that Ball was inapplicable because the dangers sought to be avoided by conspiracy and CCE are different, while the dangers in the statutes involved in Ball are the same. ${ }^{112}$ Although unwilling to extend the argument to the conclusion that all cumulative punishment is allowed, the court found that at least the punishment imposed by a conviction without an accompanying sentence did not violate the principles of double jeopardy. ${ }^{113}$

In distinguishing Ball, the Fernandez court compared the two pairs of statutes involved in the two cases. The court found that the statutes involved in Ball-receiving a firearm shipped in interstate commerce and possessing that same firearm-were overlapping statutes which Congress had not directed against separate evils. ${ }^{114}$ On the other hand, the narcotics conspiracy statute and

\footnotetext{
108 Id at 794.

107 Jeffers, 432 US at 157.

${ }^{103}$ Id.

109470 US 856 (1985).

110 Id at 864.

11916 F2d 125, 127 (3d Cir 1990).

112 Id at 127.

113 Id.

11 Id at 126, citing Ball, 470 US at 864.
} 
CCE had different purposes: "While the conspiracy statutes punish illegal agreements to import and to distribute and possess cocaine with intent to distribute, the [CCE] statute provides for punishment of persons 'trafficking in prohibited drugs on a continuing, widespread substantial and supervisory basis." "116 If it is true that the dangers protected against are not the same, then Garrett's distinction of Jeffers fails, further suggesting that Jeffers was wrongly decided.

\section{Lesser-included offenses.}

CCE and the conspiracy statutes survive a literal reading of the Blockburger test. To recall, that test provides that two statutes are different if each requires proof of a fact which the other does not. ${ }^{116} \mathrm{CCE}$ requires proof of five or more persons acting in concert, substantial income, and a "continuing series of" predicate felonies, ${ }^{117}$ while neither conspiracy statute-\$ 846 or $\S 963$-does. In addition, the two conspiracy statutes require proof of a felony object from their respective subtitles, ${ }^{118}$ while CCE does not. ${ }^{119}$ One who has committed a CCE has not necessarily violated $\S 963$, nor has a drug kingpin necessarily violated $\S 846 .{ }^{120}$ While some justices have rejected this interpretation of the Blockburger rule, ${ }^{121}$ it may be close to the original understanding of Blockburger, ${ }^{122}$ and Justice Rehnquist's opinions in recent cases suggest that at least part of the Court is moving in this direction. ${ }^{123}$

Even if conspiracy is a lesser-included offense of CCE, Blockburger's presumption-that when the elements of one offense are included in the definition of another, Congress did not intend to allow cumulative punishment for the two offenses-may not apply

116 Id at 127, citing United States v Fernandez, 822 F2d 382, 384 (3d Cir 1987).

11 Blockburger, 284 US at 304.

11721 USC $\$ 848(\mathrm{c})$.

${ }^{118}$ See 21 USC $\S \S 846,963$.

${ }_{119} 21$ USC $\S 848$ (c). For example, a CCE conviction could be based entirely upon importation charges, which fall under a different subtitle.

${ }^{120}$ One who violates the CCE statute has probably violated either $\S 846$ or $\S 963$ as well.

${ }_{122}$ See, for example, Justice Scalia's opinion in United States v Dixon, $113 \mathrm{~S} \mathrm{Ct} 2849$, 2856 (1993); Whalen v United'States, 445 US 684 (1980).

${ }_{222}$ Blockburger cited Albrecht $v$ United States, 273 US 1 (1927), as support for its test. 284 US at 304. In Albrecht, the Court found that possession of liquor and sale of the same liquor were separate offenses because one could possess liquor without selling it, and one could sell liquor without possessing it (by causing it to be sold). 273 US at 11 . See also Burton v United States, 202 US 344, 377 (1906) (one can agree to receive compensation without receiving it, and receive it without previous agreement).

${ }^{123}$ See, for example, Whalen, 445 US at 708-14 (Rehnquist dissenting). 
to compound offenses. The first evidence that Blockburger may not apply to compound offenses arose in Justice Rehnquist's dissenting opinion in Whalen: "[T] he Blockburger test, although useful in identifying statutes that define greater and lesser included offenses in the traditional sense, is less satisfactory, and perhaps even misdirected when applied to statutes defining 'compound' and 'predicate' offenses."124 Justice Rehnquist's view prevailed in Garrett-even though the Court thought that predicate offenses were lesser-included offenses of CCE, cumulative punishment for both offenses was allowed-and secured further support last term in United States $v$ Dixon. ${ }^{125}$ While it is not clear whether this view would prevail today, ${ }^{126}$ Garrett, Dixon, and lower court RICO opinions $^{127}$ make apparent at the very least that the Blockburger doctrine has been undermined when applied to compound offenses. Thus, even if conspiracy is a lesser-included offense of CCE, courts following Garrett may not presume that Congress intended to disallow cumulative punishment.

\section{Further Developments Calling JefFers Into Question}

Two changes in the law relating to punishment for compound offenses provide further support for the argument that the Jeffers reasoning should not apply to CCE and conspiracy charges, and that courts should instead impose cumulative punishments on defendants convicted of those two offenses. First, the promulgation of the Federal Sentencing Guidelines has rendered part of the Jeffers reasoning obsolete. Second, recent developments in RICO jurisprudence evince a trend toward permitting cumulative punishment for enterprise and conspiracy offenses.

\section{A. Federal Sentencing Guidelines}

At the time of Jeffers, Justice Blackmun's analysis of $\mathrm{CCE}$ - that the maximum punishment of life imprisonment does not allow for pyramiding-seemed consistent with the legislature's intent to punish drug traffickers severely. ${ }^{128}$ Congress intended

124 Id at 708.

$123113 \mathrm{~S}$ Ct 2849 . In particular, see the opinions of Justices Scalia, id at 2853, and Rehnquist, id at 2865, who agreed that Blockburger governed the case but could not agree on how to apply Blockburger to the compound offenses at issue.

128 The five different opinions in Dixon suggest disarray both in the application of Blockburger and in the determination of when Blockburger should be applied.

${ }^{127}$ See text accompanying notes 149-58.

${ }^{223}$ Jeffers, 432 US at 156. 
$\S 848$ to "serve as a strong deterrent to those who otherwise might wish to engage in the illicit [drug] traffic, while also providing a means for keeping those found guilty of violations out of circulation." 129 Although allowing the pyramiding of fines might serve as an even greater deterrent, Congress's main focus was on the length of the possible prison sentence, as it sought above all to remove those who sold narcotics on a widespread basis from the streets forever. As Senator Byrd said, the purpose of the new offense was to "remov[e] permanently from society one of the lowest forms of criminal life." 130 When Congress enacted $\S 848$ in 1970, and even when Jeffers was decided in 1977, the statute satisfied this goal by authorizing a lifetime prison sentence for repeat drug offenders. ${ }^{131}$ The only restraint the original $\S 848$ placed on the sentencing judge was a $\$ 100,000$ cap on the fine that could be imposed..$^{132}$

The subsequent promulgation of the Federal Sentencing Guidelines changed the structure of the CCE statute by reducing the maximum sentence to less than life imprisonment for some violations. Under the Federal Sentencing Guidelines, courts must either impose sentences within a particular range, or specify reasons, also limited by the Guidelines, whenever they deviate from the range. ${ }^{133}$ Under the Guidelines, sentences for violations of the Controlled Substances Act are generally set according to the amount of drugs involved. ${ }^{134}$ And, although the allowable sentences for CCE are harsh, in some circumstances the sentence may be capped at less than life, leaving room to cumulate prison terms. ${ }^{136}$ As a result of this change in sentencing procedure, the Jeffers argument that

129 See HR Rep 91-1444 (Part 1), 1970 USCCAN at 4576 (cited in note 3).

130116 Cong Rec 1183 (Jan 26, 1970).

132 USC $\$$ 848(a)(1) (1982).

13221 USC \& 848(a)(1) (1970). Repeat offenders could be fined up to $\$ 200,000$. Id.

${ }^{133} 18$ USC $\S 3553(b)$ (1988). See also Robert W. Haines, Jr., Kevin Cole, and Jennifer C. Woll, Federal Sentencing Guidelines Handbook § 1A3-1A4 at 5-10 (McGraw-Hill, 1992) ("Guidelines Handbook").

${ }^{134}$ See, for example, Guidelines Handbook § 2D1.1 at 165 and Sentencing Table, § 5A at 462 (providing for 30 years to life imprisonment for possession of 300 kilograms or more of heroin or 1500 kilograms or more of cocaine).

${ }^{135}$ See id $\S 2 D 1.1$ at $167-75, \S 2 D 1.5$ at 198 , and Sentencing Table, $\S 5 A$ at 462 . While in some of these cases the Guidelines may be correct in not authorizing consecutive prison terms (for example, 20 years for conspiracy plus 30 years for $\mathrm{CCE}$, for a total of 50 years), it is only correct because in these cases the CCE sentence necessarily includes punishment for the predicate conspiracy, which the Guidelines use to calculate the sentence for CCE. That is to say, the CCE sentence is already cumulated. See id $\S 2 D 1.5$ and text accompanying notes $141-47$. In any event, if the maximum sentence is less than life, by definition, there is room to pyramid. 
$\S 848$ leaves no room for pyramiding sentences is somewhat undermined.

The Federal Sentencing Guidelines also represent an interpretation of congressional intent with respect to cumulative punishment for CCE and conspiracy. Congress has delegated to the Federal Sentencing Commission the power to determine the amount of the fine and length of the prison sentence to be imposed in criminal cases, as well as the determination of whether sentences should run concurrently. ${ }^{136}$ The sentences, of course, must be consistent with the penalties allowed by the statutory provision outlawing particular behavior. ${ }^{137}$

Thus, it appears that Congress has delegated to the Sentencing Commission the power to construe congressional intent with respect to whether multiple punishments are allowed for violations of two statutory provisions, and Congress has made such interpretations binding on the courts: "The court shall impose a sentence of the kind, and within the range [set forth in the Sentencing Commission's guidelines], unless the court finds that there exists an aggravating or mitigating circumstance of a kind, or to a degree, not adequately taken into consideration by the Sentencing Commission in formulating the guidelines. . . "138 The Sentencing Commission has interpreted the CCE and conspiracy statutes to allow cumulative punishment by requiring predicate offenses to be used in calculating the CCE offense. ${ }^{139}$ If Congress did not intend cumulative sentencing, then any consideration of the conspiracy in sentencing for CCE should be impermissible ${ }^{140}$ and therefore outside the scope of the Sentencing Commission's delegation.

Application of the Federal Sentencing Guidelines also suggests that conspiracy and CCE should be cumulatively punished. First, the base offense level for CCE is the sum of the levels for the underlying predicate offenses plus an additional penalty. ${ }^{141}$ The Guidelines also treat conspiracy and substantive sentences identically: the punishment for conspiracy, whether as an independent conviction or as a predicate for $\mathrm{CCE},{ }^{142}$ is the same as if the object

136 See 28 USC $\S \S 994(a)(1)(B)$ and $994(a)(1)(D)$ (1988). See also Mistretta $v$ United States, 488 US 361, 374, 390-91 (1989).

${ }^{137}$ See 28 USC $\S 994(b)(1)$.

13818 USC $\S 3553(\mathrm{~b})$.

239 Guidelines Handbook § 2D1.5 at 198.

${ }_{140}$ See, for example, United States v Bafia, 949 F2d 1465, 1473-75 (7th Cir 1991).

142 Guidelines Handbook $\S 2 D 1.5$.

142 Id. Until 1992, the Guidelines only included substantive predicate offenses in calculating the offense level for CCE. Guidelines Handbook §§ 2D1.1, 2D1.4, 2D1.5. Moreover, 
of the conspiracy had been completed. ${ }^{143}$ The defendant serves all of his sentences concurrently. ${ }^{144}$ Thus, a defendant convicted on one count of manufacture, one count of distribution, one count of conspiracy under $\S 848$, and CCE based on the other three preceding offenses will have four convictions and four sentences. The CCE sentence will be the sum of the sentences for the other three offenses plus an extra penalty; all the sentences will run concurrently. ${ }^{145}$

The Guidelines advocate punishing a conspirator as if he had completed the object of the conspiracy. ${ }^{146}$ This approach is consistent both with the language of $\S 846$ and $\S 963$ and with some of the modern theories of punishing conspiracy, which suggest that two elements of the conspiracy require punishment: the agreement and the object. ${ }^{147}$ While punishment for CCE includes a penalty for the agreement, it may not reflect the object of the conspiracy. Thus, for the punishment to fit the crime, the defendant should be sentenced cumulatively for both conspiracy and CCE.

Furthermore, failure to enhance a sentence for conspiracy would be inconsistent with congressional intent. Sections 846 and 963 and the Guidelines express Congress's intent: the defendant must be punished for the object of the conspiracy. Sentencing for CCE without including the substantive object of the conspiracy would result in a lighter sentence than Congress intended for conspirators and organized crime leaders. Thus, when imposing a sentence on a defendant convicted of both CCE and conspiracy, courts should use as the base offense level the sum of each of the predicate offenses, including the object of the conspiracy, and the additional penalty for CCE. Because the Guidelines also retain the in-

because every Court of Appeals to address the issue has concluded that a conspiracy may be a predicate offense, it is appropriate to consider the object of the conspiracy in sentencing. See, for example, United States $v$ Fernandez, 822 F2d 382, 384-85 (3d Cir 1987); United States $v$ Young, $745 \mathrm{~F} 2 \mathrm{~d} 733,750$ (2d Cir 1984). See also United States $v$ Bond, 847 F2d 1233, $1238 \mathrm{n} 1$ (7th $\mathrm{Cir} 1988$ ) (not deciding the issue, but citing cases).

${ }^{143}$ Guidelines Handbook $\S 2 \mathrm{D} 1.1$ at 165 . However, the Guidelines also state that all drug offenses should be grouped together for sentencing purposes. If more than one guideline can be used to calculate an offense level, the greatest base offense level shall be used to determine sentencing. Id $\S \S 3 \mathrm{D} 1.1-3 \mathrm{D} 1.3$. Thus, the Guidelines may require different treatment when a defendant is convicted of conspiracy, the completed crime, and CCE.

144 Id $\S 5$ G1.2.

145 It is less clear whether the Guidelines authorize cumulative fines. Under Guideline $\S 5 \mathrm{E} 1.2$, the sentencing court may impose a fine up to the statutory maximum. Id $\S 5 \mathrm{E} 1.2$. Thus, in some cases, fines for separate offenses may need to be cumulated in order to effectuate Congress's intent.

${ }^{148}$ Id § $2 \mathrm{D} 1.1$ at $165,196$.

${ }^{167}$ See, for example, MPC \& 5.05(1). 
dividual convictions for the predicate offenses, ${ }^{148}$ the overall sentence reflects both the defendant's role in the conspiracy and his criminal enterprise. This is the only result that is consistent with congressional intent; is it also within the ambit of the Guidelines.

\section{B. Cumulative Punishment in the RICO Context}

A comparison of cumulative punishment for conspiracy and CCE to the RICO conspiracy and enterprise offenses ${ }^{149}$ also adds weight to the theory that cumulative punishment under the Controlled Substances Act does not violate the Double Jeopardy Clause. Most commentators who examine the issue of double jeopardy as it pertains to CCE compare it to RICO (and RICO conspiracy), since both crimes require predicate acts, and both were enacted to combat organized crime. ${ }^{\mathbf{1 5 0}}$ Since Garrett, most courts have found that RICO enterprise and RICO conspiracy offenses may be punished cumulatively, ${ }^{161}$ and that RICO conspiracy and a predicate offense may be punished cumulatively. ${ }^{152}$ Thus, the

148 Guidelines Handbook § 5G1.2.

140 The Racketeer Influenced and Corrupt Organizations provisions specify:

(a) It shall be unlawful for any person who has received any income . . . from a pattern of racketeering activity or through collection of an unlawful debt in which such person has participated as a principal . . . to use . . . any part of such income . . . in acquisition of any interest in . . . any enterprise which is engaged in . . . interstate or foreign commerce. . . .

(b) It shall be unlawful for any person through a pattern of racketeering activity or through collection of an unlawful debt to acquire or maintain . . . any interest in . . . any enterprise which is engaged in . . . interstate or foreign commerce.

(c) It shall be unlawful for any person employed by . . . any enterprise engaged in ... interstate or foreign commerce, to conduct or participate ... in the conduct of such enterprise's affairs through a pattern of racketeering activity ....

(d) It shall be unlawful for any person to conspire to violate any of the provisions of subsection (a), (b), or (c) of this section.

18 USC \& 1962 (1988).

${ }^{180}$ See, for example, Twenty-Second Annual Review of Criminal Procedure: United States Supreme Court and Courts of Appeals, 1991-1992, 81 Georgetown L J 853, 1240 1244 (1993); Anne Bowen Poulin, Double Jeopardy Protection Against Successive Prosecutions in Complex Criminal Cases: A Model, 25 Conn L Rev 95, 132 (1992); Susan W. Brenner, Of Complicity and Enterprise Criminality: Applying Pinkerton Liability to RICO Actions, 56 Mo L Rev 931, 990-1005 (1991) (using CCE analogy in RICO context); Comment, Double Jeopardy, Complex Crimes and Grady v Corbin, 60 Fordham L Rev 351, 351 n 2, 362-64 (1991) (same).

${ }^{181}$ See, for example, United States $v$ West, 877 F2d 281, 292 (4th Cir 1989); United States $v$ Watchmaker, 761 F2d 1459, 1477 (11th Cir 1985). But see United States v Sutton, 642 F2d 1001, 1040 (6th Cir 1980) (en banc) (holding that where evidence of RICO conspiracy and violation is identical, the two charges must merge for sentencing).

${ }^{182}$ See, for example, United States v Pungitore, 910 F2d 1084, 1107-11 (3d Cir 1990). 
RICO cases suggest that Jeffers may be decided differently if heard today.

More than one court has held that the Double Jeopardy Clause does not bar cumulative punishment for RICO conspiracy and a predicate conspiracy offense. ${ }^{153}$ Although these cases are not dispositive in the drug context, their more modern reasoning is readily applicable. For instance, United States $v$ Pungitore determined that the same reasoning underlying the Court's decision in Garrett allowed cumulative punishment for RICO conspiracy and a conspiracy predicate offense. ${ }^{\mathbf{1 5 4}}$ Pungitore relied on an earlier case in the same circuit, United States $v$ Grayson, that had applied the Garrett logic to RICO and substantive predicate offenses and had found cumulative punishment constitutional. ${ }^{155}$ Grayson held that the language and legislative history of RICO suggested that Congress sought to allow cumulative sentencing for predicate offenses and RICO offenses (including RICO conspiracy). ${ }^{156}$ Pungitore could find "no principled way to distinguish [conspiracy] from [the earlier predicate offense]."157 The court reasoned that the legislative intent that allowed cumulative punishment for RICO and its underlying predicate offenses applied equally well to conspiracies as predicate offenses. ${ }^{168}$ This reasoning also applies to the parallel crimes of conspiracy and CCE: if the legislature intended cumulative punishment for $\mathrm{CCE}$ and substantive predicate offenses, it probably intended it for conspiracy predicate offenses as well.

\section{Conclusion}

The Double Jeopardy Clause does not prohibit cumulative punishment for conspiracy and continuing criminal enterprise. While a plurality of the Supreme Court held in Jeffers $v$ United States that Congress did not intend to allow cumulative punishment in this situation, developments in the law since that decision have severely undermined the Jeffers reasoning. Because these developments have always distinguished Jeffers, and because Jeffers has never been expressly overruled, lower courts have continued to

${ }^{163}$ Id. See also United States v Kragness, 830 F2d 842, 863-64 (8th Cir 1987); United States v Mitchell, 777 F2d 248, 264 (5th Cir 1985) (finding that drug conspiracy and RICO conspiracy were "separate offenses" under Blockburger).

${ }^{164}$ Pungitore, $910 \mathrm{~F} 2 \mathrm{~d}$ at $1108 \mathrm{n} 24$.

1ss 795 F2d 278, 286 (3d Cir 1986).

${ }^{158} \mathrm{Id}$.

$257910 \mathrm{~F} 2 \mathrm{~d}$ at $1108 \mathrm{n} 24$.

188 Id. 
follow Jeffers rather than permitting cumulative punishment for conspiracy and CCE.

These recent developments suggest that Jeffers should be reexamined and reversed. The analysis of CCE in Garrett supports this view. The language, structure, and legislative history of the CCE statute, as well as the two conspiracy statutes in the Comprehensive Drug Abuse Prevention and Control Act, show that Congress intended for CCE to be an offense separate from each of the narcotics conspiracy statutes. Furthermore, the Federal Sentencing Guidelines allow the conspiracy to be considered in calculating the sentence for CCE and then allow a sentence for conspiracy to run concurrently, providing further evidence that Congress intended for the two offenses to be punished cumulatively. Finally, courts applying Garrett in the RICO context have permitted cumulative punishment for RICO conspiracy and conspiracies as predicates to the RICO enterprise. 
